\title{
RESEARCH ISSUES AND PRIORITIES IN THE FIELD OF AGRICULTURE SECTOR AND DAIRY SCENARIO OF TRIPURA A CRITICAL ANALYSIS
}

\author{
Miltan Kumar Acharjee ${ }^{1}$, A.K.Ray ${ }^{2}$ \\ ${ }^{I}$ Research Scholar, Department of Humanities \& Social Science, National Institute Technology, Agartala, India \\ \&Lecturer in Management at Bhavan's Tripura College of Science \&technology, Agartala \\ E-mail id-mm3798@gmail.com \\ ${ }^{2}$ Prof \&HOD Department of Humanities and Social Science, National Institute Technology, Agartala, India \\ E-mail-ajitkumarray1949@gmail.com
}

\begin{abstract}
Indian Agriculture is an economic symbiosis of crop production and animal rearing. In India 70 percent population and their livelihood is depending upon the agriculture. Same scenario is applicable for Tripura as well as the same North East India. Agriculture is an important sector in the economy of the North East Region (NER), with its share in state domestic product (SDP) ranging from 19 percent to 37 percent in different states. In Tripura the total population of $70 \%$ population and their livelihood is dependents on the agriculture. The paper contributes to the effectual research is very necessary and their implacability to continued development process in agriculture at Tripura. On the other aspects is animal, husbandry which is really substitute occupation for agriculture. one is dependent on another. Animal Husbandry is a state subject and the State Governments are primarily responsible for the growth of the sector. The Department of Animal Husbandry, Dairying \& Fisheries has, however, been operating 30 Central Livestock Organizations and allied Institutions for production and distribution of superior germ plasms to the State Governments for cross breeding and genetic upgradation of the stocks. Besides, the Department has been implementing 11 Central Sector and Centrally Sponsored Schemes for the development of requisite infrastructure and supplementing the efforts of the State Governments for achieving the accelerated growth of animal husbandry sector. The study mainly focuses the issues of problems, present status of animal husbandry and agriculture sector in Tripura.
\end{abstract}

Keyword: Animal Husbandry, crossbreed Cattle, Research Priorities, Sri (System Rice intensification) etc.

\section{INTRODUCTION}

Indian Agriculture is an economic symbiosis of crop production and animal rearing. In India 70 percent population and their livelihood is depending upon the agriculture. Same scenario is applicable for Tripura as well as the same North East India. Agriculture is an important sector in the economy of the North East Region (NER), with its share in state domestic product (SDP) ranging from 19 percent to 37 percent in different states. In Tripura the total population of $70 \%$ population and their livelihood is dependents on the agriculture. The paper contributes to the effectual research is very necessary and their implacability to continued development process in agriculture at Tripura. Agriculture is the core of socio economic development at Tripura .Not only it is source of livelihood and food security for large population in India as well as North east remote state Tripura but also has a special significance for low income, poor and vulnerable sections. In Tripura Government has given the priorities various research issues of the agricultural sector special aspects crops production. Their main objective is to use the improvised and modernized technology for being the increase production of various crops. With a short span of time how utilize the minimum resource and to get the maximum output. The main research issue is how to motivate the people and given the knowledge about that agriculture is the prior concern of human beings and it is most profitable arena of business as well as state development.

In case of Tripura, The revised perspective plan(RPP) on agriculture and allied activities aims at attaining self stuffiness in food production by 2012.Finally the total area in Tripura 10,491.69 km and agricultural land is 6,40,422 which is maximum used in the purpose of rice production. Tripura having four districts(West, South, Dhalai and North).Out of four districts the main land of agricultural sector is West districts area like Teliamura, Khowai, Moharchara etc.These are the places mainly produces crops as well as vegetables. But due to lack of knowledge of farmers about the crop production they are not getting the output properly, so that here agricultural research people are more essential to stay 
with them and provide upto date knowledge about the agriculture.

Animal Husbandry is a state subject and the State Governments are primarily responsible for the growth of the sector. The Department of Animal Husbandry, Dairying \& Fisheries has, however, been operating 30 Central Livestock Organizations and allied Institutions for production and distribution of superior germ plasms to the State Governments for cross breeding and genetic upgradation of the stocks. Besides, the Department has been implementing 11 Central Sector and Centrally Sponsored Schemes for the development of requisite infrastructure and supplementing the efforts of the State Governments for achieving the accelerated growth of animal husbandry sector. The animal husbandry sector is being considered as one of the major activities for providing subsidiary income during non-harvesting season of the farming families in Tripura. Over the period of time due to tremendous potential of the sector opened up due to breed upgradation, scientific management practices, this sector is now ushering as a principal source of income to many farmers. The state government has been encouraging and strengthening its effort for taking this advantage in this sector.

In Tripura 5 lakhs of population of their livelihood is depending on the farming of animal Husbandry. The major percentage is cattle faming, means a milk production.

Animal Husbandry Department was tagged under the Agriculture Department. During second Plan Period (1956-61) the Animal Husbandry sector was handed over to the Tripura Territorial Council (TTC). Chief Executive officer was the head of the Department. During the third Plan Period (196166) the TTC handed over the Department to Tripura Administration in the year 1965-66 and on November 1969 Animal Husbandry was accorded independent status and named as Directorate of Animal Husbandry. The department was renamed as Department of Animal Resources Development in the year 1993.In Tripura most famous area for Animal Husbandry is Gwalabasti and R.K.Nagar farm which is situated at Agartala.

\section{OBJECTIVES OF THE STUDY:}

To identify the problems of Agriculture and Animal Husbandry sector in Tripura.

* To identify and categorize high priority research topics in agricultural Sector and Animal Husbandry Sector.

* To examine which research priorities are being addressed at state level regarding Agriculture and Animal Husbandry Sector.

* To examine the Present Status of Animal Husbandry Sector Special reference to Cross Breed.

\section{METHODOLOGY:}

Data Collected: Primary and Secondary data.

Data collection Area: Agartala, Tripura.

Data collection method: In-depth interview with research extension and education specialists and different literature of Animal Husbandry Department, web articles,journal etc.

Sample Size: 10 Expert members

Secondary data from: Govt. of India Source, Govt.of Tripura Source, Web Articles and Journals etc.

\section{LITERATURE REVIEW:}

Mahatma Gandhi said "Indian economy lives in rural villages", and many of the industries getting their raw material from agriculture sector. Gandhi also said "Agriculture is the main backbone of Indian economy." According to Jaydip Chakraborty, "Agriculture - the backbone of civilization - is facing multitude of problems mainly owing to increase in population and slow growth in food production. In the era of Liberalization, Privatization and Globalization (LPG) too much emphasis on industrial growth has rendered the agriculture sector of the country uncared. The plan laid stress on usage of hybrid seeds for increased crop production along with emphasis on bio-fertilizer utilization to lessen dependence on chemical fertilizers. The plan also stressed on Watershed Management in rain-fed cultivation. However, a section of experts is doubtful about attaining the target set by the RPP mainly due to inapt processes of policy implementation. It is true that odds are high, but it will be unwise to ponder the strength of the State that can certainly play the role of a catalyst in achieving growth in agriculture." According to Dr. Kwadeo Asenso-okere, Regional Director of International Food policy Research Institute (IFPRI) on 3 day International Seminar held at Agartala shared his vast experience "one of the causes of slow Agricultural growth attributed to lack of motivation among the farmers to cultivate. "Agricultural development is highly related with overall development of the rural areas and its people. To motivate the rural people for agri-activities, it is essential to ensure easy access to basic amenities and agriculture knowledge in the rural areas"Dr.Kwadeo suggested, steps to make a agriculture a profitable profession will attract competent people in agrisector. Policies should focus on capacity building to enable the farmers access the latest information on agri-activities. To this end, the State is doing well in maintaining peace and implementing several social security schemes like MGNREGA. The need of this hour is to draw a vibrant approach with a focus on strict "monitoring-endowmentevaluation-redrawing policies" model. Sincere evidence-based monitoring will help to formulate appropriate endowment policies. 'Agricultural Technology Management Agency' (ATMA) at district level.

In Tripura, ATMA conducted total 1745 nos of technology demonstration in all over the State. So far, 16 farmer-scientist interactions were arranged. Farmers of several remote villages successfully increased area of various cultivations with the 
knowledge assistance from ATMA. With all the weaponries ready, to attain self-sufficiency in food production the State Administration along with the Agri-Department should become more pro-active in implementing the policies and take drastic steps to manage the farm economies in scientific manner and overcome some of the challenges that the State Agriculture is currently facing. The main issues and challenges of Agriculture in India the need of the hour is not an application of technology, which would suit the particular level of global community. In India farming practices are too haphazard and non-scientific and hence need some forethought before implementing any new technology. Thus, the information on spatial variability in soil fertility status and crop condition is aprerequisite for adoption of precision farming. Space technology including global posting system(GPS) and GIS holds goods promise in deriving information on soil attributes and Crop yield and allows monitoring seasonally -variable soil and crop characteristics ,namely soil moisture ,Crop phenology ,growth ,evapotranspiration,Crop diseases etc.President of India keen to support Agricultural research in dry areas .

During her State visit to Syria, the President visited ICARDA's headquarters in Aleppo, Syria, yesterday - her first visit to any international agricultural research center. She toured field and lab facilities. Dr Mahmoud Solh, ICARDA Director General, presented the Center's work in dry areas worldwide, highlighting the joint projects with research organizations in India. Dr Solh described how results from these projects are benefiting dry land farmers in India and in many developing countries. Collaborative projects, in partnership with the Indian Council of Agricultural Research (ICAR) and its various institutions, the National Rainfed Area Authority, and agricultural universities in India, cover a number of areas, including development of new high-yielding crop varieties, rainwater harvesting, water-use efficiency, livestock husbandry, and socio-economics and policy. These projects focus on increasing production of pulse crops, strengthening crop-livestock systems in drylands, and promoting value-added products to increase farmers' income.The President expressed hope that partnerships between ICARDA and Indian research organizations would grow even stronger. "Research organizations such as ICARDA can help ensure food security - and thereby, ensure welfare for all humanity," said the President.

Hi-Tech commercial Dairy as a new plan scheme is proposed to be implemented in the State starting from the year 2008-09 project assistance could be provided," the President added. It needs no emphasis that India happens to be the goldmine of farm livestock resources.

\section{Problems of Agricultural AND Animal}

\section{HUSBANDRY SECTOR IN TRIPURA:}

* In general the Agricultural Sector in Tripura is facing the following problems:

* In Tripura Agricultural land and Animal Husbandry farming land decreasing day by day due to population increases.

* Indo Bangla fancing decreases Agricultural land.

* Labour shortages, skill labour is not available in the agricultural field as well as Animal Husbandry Sector according to the primary source.

* Lack of trained and research people in the Agricultural dimension in Tripura.

* Most of the farmers are not motivated of their own self to cultivate crops again and again.

* In rural area of Tripura people are conscious to make their career to various field like service ,business etc but generally don't want to take Agriculture and Animal Husbandry as their profession of Livelihood.

* Peoples especially Tribes are not habituated enough to cattle as well as fodder farming.

* One of the important constraints for Animal Husbandry farming is hilly areas.

* Less awareness programme provide to the famers regarding various advance technology of Animal Husbandry.

* People are not interested to animal farming again and again because cost, hard work is more but output is less.

* Shortage of feed and fodder.

* Farmers are not enough educated in both the sector.

\section{IDENTIFICATION AND CATEgORIZATION OF HIGH} PRIORITY RESEARCH TOPICS IN AGRICULTURAL

\section{SECTOR AND ANIMAL HUSBANDRY:}

During the interaction with the research specialists from State agriculture research centre it is revels that the prioritized research areas in the Agriculture sector are as follows:

* Increase of the productivity of different agriculture crops mainly Paddy.

* Impact /Adverse affect assessment of climate changes on Agriculture sector.

* Research on water scarcity in future specifically by 2050.

* Improvement of Shifting Cultivation. Etc.

* Research on Cross-Bred cattle farming.(Combination of Non-Descript or Jersey Cows) 


\section{RESEARCH PRIORITIES ARE BEING ADDRESSED}

AT

\section{STATE LEVEL:}

Though all the above mentioned areas are equally important to the State agriculture research centre but they are addressing the Increase of the productivity of different agriculture crops mainly Paddy at the State level. In Case of Animal Husbandry Department of Tripura given research priority on Cross Breed farming to increase the milk production.For this purpose they have taken various significant initiatives through SRI production technique. For example: These following table will give a picture that how through SRI Area and Target Coverage of Agriculture land and Crops production are being achieved including the research are going on the variety of agriculture crops mainly Paddy.

Table -1: SRI Area and Target Coverage

\begin{tabular}{|c|c|c|c|}
\hline Year & $\begin{array}{c}\text { Area } \\
\text { covered } \\
\text { under SRI } \\
\text { (ha) }\end{array}$ & $\begin{array}{c}\text { Total Paddy } \\
\text { Area (ha) }\end{array}$ & $\begin{array}{c}\text { Per cent } \\
\text { Covered } \\
\text { through } \\
\text { SRI (\%) }\end{array}$ \\
\hline $2002-03$ & 8.8 & $2,39,670$ & 0.003 \\
\hline $2003-04$ & 17.6 & $2,42,110$ & 0.007 \\
\hline $2004-05$ & 176 & $2,38,950$ & 0.07 \\
\hline $2005-06$ & 352 & $2,37,150$ & 0.14 \\
\hline $2006-07$ & 14,678 & $2,35,272$ & 6.23 \\
\hline $2007-08$ & 32,497 & $2,35,938$ & 13.77 \\
\hline $2008-09$ & $39,490.5$ & $2,28,710$ & 17.26 \\
\hline $2009-10$ & $59,577.5$ & $2,29,897$ & 25.91 \\
\hline $2010-11$ & 41,693 & $1,48,000$ & 28.1 \\
\hline Kharif) & & & \\
\hline
\end{tabular}

Table -2: Progeny Row Trial KHARIF 2010-11

\begin{tabular}{|l|l|c|c|c|}
\hline $\begin{array}{l}\text { Sl. } \\
\text { No. }\end{array}$ & $\begin{array}{l}\text { Name of } \\
\text { HYV } \\
(100 \text { panicles }\end{array}$ & $\begin{array}{l}\text { Area } \\
\text { Target } \\
\text { (in } \\
\text { each })\end{array}$ & \multicolumn{2}{|c|}{ Production Target(in } \\
\cline { 4 - 5 } & Breeder & $\begin{array}{c}\text { Nucleus } \\
\text { Seeds }\end{array}$ & Seeds \\
\hline 1. & Satabdi & $\begin{array}{c}0.10 \\
\text { ha }\end{array}$ & $80 \mathrm{kgs}$ & $04 \mathrm{kgs}$ \\
\hline 2. & Krishnahamsa & $\begin{array}{c}0.10 \\
\text { ha }\end{array}$ & $85 \mathrm{kgs}$ & $05 \mathrm{kgs}$ \\
\hline 3. & MTU-7029 & $\begin{array}{c}0.10 \\
\text { ha }\end{array}$ & $90 \mathrm{kgs}$ & $06 \mathrm{kgs}$ \\
\hline 4. & Pooja & $\begin{array}{c}0.10 \\
\text { ha }\end{array}$ & $90 \mathrm{kgs}$ & $06 \mathrm{kgs}$ \\
\hline 5. & Naveen & $\begin{array}{c}0.10 \\
\text { ha }\end{array}$ & $85 \mathrm{kgs}$ & $05 \mathrm{kgs}$ \\
\hline 6. & NDR-97 & $\begin{array}{c}0.10 \\
\text { ha }\end{array}$ & $90 \mathrm{kgs}$ & $06 \mathrm{kgs}$ \\
\hline 7. & Kalikhasa & $\begin{array}{c}0.10 \\
\text { ha }\end{array}$ & $65 \mathrm{kgs}$ & $03 \mathrm{kgs}$ \\
\hline
\end{tabular}

\begin{tabular}{|c|l|c|c|c|}
\hline 8. & Sonamashuri & $\begin{array}{c}0.10 \\
\text { ha }\end{array}$ & $70 \mathrm{kgs}$ & $03 \mathrm{kgs}$ \\
\hline 9. & NDR-359 & $\begin{array}{c}0.10 \\
\text { ha }\end{array}$ & $65 \mathrm{kgs}$ & $03 \mathrm{kgs}$ \\
\hline 10. & IET-17612 & $\begin{array}{c}0.10 \\
\text { ha }\end{array}$ & $85 \mathrm{kgs}$ & $03 \mathrm{kgs}$ \\
\hline 11. & IR-64 & $\begin{array}{c}0.10 \\
\text { ha }\end{array}$ & $80 \mathrm{kgs}$ & $04 \mathrm{kgs}$ \\
\hline 12. & Uphar & $\begin{array}{c}0.10 \\
\text { ha }\end{array}$ & $85 \mathrm{kgs}$ & $05 \mathrm{kgs}$ \\
\hline 13. & Pratiksha & $\begin{array}{c}0.10 \\
\text { ha }\end{array}$ & $90 \mathrm{kgs}$ & $06 \mathrm{kgs}$ \\
\hline 14. & Harinarayan & $\begin{array}{c}0.10 \\
\text { ha }\end{array}$ & $70 \mathrm{kgs}$ & $03 \mathrm{kgs}$ \\
\hline
\end{tabular}

Table -3: Nuclear-Breeder Seed Production Programme.

\begin{tabular}{|c|c|c|c|}
\hline $\begin{array}{c}\text { Sl. } \\
\text { No. }\end{array}$ & $\begin{array}{c}\text { Name of } \\
\text { varieties }\end{array}$ & $\begin{array}{c}\text { Area to be } \\
\text { covered(in } \\
\text { ha) }\end{array}$ & $\begin{array}{c}\text { Production } \\
\text { Target(in kgs) }\end{array}$ \\
\hline 1 & $\begin{array}{c}\text { Harinaraya } \\
\text { n }\end{array}$ & 1.20 ha & 3600 \\
\hline 2. & Tapaswani & 0.10 ha & 400 \\
\hline 3. & Satabdi & 0.10 ha & 350 \\
\hline
\end{tabular}

To examine the Present Status of Animal Husbandry Sector SPECIAL REFERENCE TO Cross BREed

The objective of Animal Husbandry Department is to supply the sufficient Protein the way of Milk, Egg and Meat. Here discussing the fact is Milk production through Cross- Breed .Table-04 show that the existing Cross -Breed status

It shows that existing status of Cross-Breed Milk Cows, Gross total is including 4 districts in Tripura is 18,949 number. Total Cattle 94, 8278 number, total CB female 61,150 ,total ,Total Non - Descriptive in Milk 14,5788.Total ND Female 515176,total Cattle 94,8278 number, number, total ND cattle 847435number. 


\begin{tabular}{|l|l|l|l|l|l|l|l|l|l|l|l|}
\hline $\begin{array}{l}\text { Sl } \\
\text { No. }\end{array}$ & District & $\begin{array}{l}\text { CB in } \\
\text { Milk }\end{array}$ & $\begin{array}{l}\text { Total CB } \\
\text { Female }\end{array}$ & $\begin{array}{l}\text { Total CB } \\
\text { Cattle }\end{array}$ & $\begin{array}{l}\text { ND in } \\
\text { Milk }\end{array}$ & $\begin{array}{l}\text { Total } \\
\text { ND } \\
\text { Female }\end{array}$ & $\begin{array}{l}\text { Total } \\
\text { ND } \\
\text { Cattle }\end{array}$ & $\begin{array}{l}\text { Total } \\
\text { Cattle }\end{array}$ & $\begin{array}{l}\text { Buff.in } \\
\text { Milk }\end{array}$ & $\begin{array}{l}\text { Total } \\
\text { Female } \\
\text { Buffalow }\end{array}$ & $\begin{array}{l}\text { Total } \\
\text { Female } \\
\text { Buffalow }\end{array}$ \\
\hline 1 & 2 & 3 & 4 & 5 & 6 & 7 & 8 & 9 & 10 & 11 & 12 \\
\hline 1 & West & 11391 & 36901 & 42830 & 55445 & 203045 & 329814 & 373644 & 188 & 1016 & 1809 \\
\hline 2 & South & 4365 & 14334 & 18038 & 46938 & 163559 & 276834 & 294872 & 574 & 2005 & 3688 \\
\hline 3 & North & 1707 & 5739 & 7106 & 27095 & 93007 & 162574 & 1699680 & 1033 & 4954 & 7007 \\
\hline 4 & Dhalai & 1486 & 4176 & 5569 & 16310 & 55565 & 105513 & 111082 & 369 & 1054 & 1656 \\
\hline & Gr.Total & 18949 & 61150 & 73543 & 145788 & 515176 & 874735 & 874735 & 2164 & 9029 & 14160 \\
\hline
\end{tabular}

Table-4 Important Figures of $18^{\text {th }}$ live stock census-2007 in Tripura State. (Provisional Report)

\section{CB- CROSS -BREED}

ND - NON- DESCRIPT (DESI COWS)

\section{CROSS-BREED AND ND YEAR WISE QUINQUENNIAL GROWTH}

Table-5 Cross and ND year wise Quinquennial growth.

\begin{tabular}{|c|c|c|c|c|c|}
\hline Sl no & Kind of Live Stock & $\begin{array}{l}\text { Population as per } 17^{\text {th }} \\
\text { LSC, } 2003\end{array}$ & $\begin{array}{l}\text { Population as per } \\
18^{\text {th }} \text { LSC, } 2007\end{array}$ & $\begin{array}{l}\text { Growth Rate } \\
\text { over2003 (\%) }\end{array}$ & $\begin{array}{l}\text { Yearly Growth } \\
\text { rate }\end{array}$ \\
\hline 1 & 2 & 3 & 4 & 5 & 6 \\
\hline 1 & CB Cow in milk & 18041 & 18949 & $5.03 \%$ & $1.30 \%$ \\
\hline 2 & ND cow in milk & 135475 & 145788 & $7.61 \%$ & $1.90 \%$ \\
\hline 3 & Total female(CB\&ND) & 434569 & 576326 & $32.62 \%$ & $8.16 \%$ \\
\hline 4 & Total CB cattle & 57304 & 73543 & $28.34 \%$ & $7.09 \%$ \\
\hline 5 & Total ND cattle & 701872 & 874735 & $24.62 \%$ & $6.16 \%$ \\
\hline 6 & Total cattle & 759176 & 948278 & $24.90 \%$ & $6.23 \%$ \\
\hline
\end{tabular}


Table -5 shows that Cross- Breed number increase in year wise.The observation found that 2003 CB number was 18041 and 2007 that number is 18949.Year wise percentage increase is $1.30 \%$.Total Cattle in the year 2003 the number was 75916 and yearly growth rate is $6.23 \%$. Major default in the year 2007 total Buffalow percentage is $(-2.01) \%$ and it was negative growth. 2003 the total Buffalow number is 14,45 and i.e going to be decrease in the year of 200714,160 .

\section{InTEgRATED SMAPLE SURVEY RePORT (2009-}

\section{0)}

\section{Season Wise Milk Production Status in the}

\section{YEAR (2009-2010) IN TRIPURA}

Per capita availability of local Milk is approximately 76.08 gms. daily during the year (2009-2010).

Table-06 shows that West Tripura total Milk production in a year 2009-2010 45048.43 in ltrs.South Tripura total Milk production in a year 29278.33 Ltrs. North Tripura and Dhalai District milk production respectively 10331.39 Ltrs. Whole Tripura Milk productions 1,00,640.39 in ltrs.

Table-6 Season Wise Milk Production Status in the year (2009-2010) in Tripura.

\begin{tabular}{|l|l|l|}
\hline $\begin{array}{l}\text { Name of the } \\
\text { District }\end{array}$ & Name of Season & $\begin{array}{l}\text { Milk Production } \\
\text { (in MT) }\end{array}$ \\
\hline 1 & $\mathbf{2}$ & $\mathbf{3}$ \\
\hline West Tripura & Summer & 14592.95 \\
\cline { 2 - 3 } & Monsoon & 15020.61 \\
\cline { 2 - 3 } & Winter & 15434.87 \\
\cline { 2 - 3 } & Total & 45048.43 \\
\hline South Tripura & Winter & 9489.56 \\
\cline { 2 - 3 } & Monsoon & 9767.71 \\
\cline { 2 - 3 } & Winter & 10021.06 \\
\cline { 2 - 3 } & Total & 29278.33 \\
\hline North Tripura & Winter & 5182.68 \\
\cline { 2 - 3 } & Monsoon & 5333.26 \\
\cline { 2 - 3 } & Summer & 5466.30 \\
\cline { 2 - 3 } & Total & 3446.47 \\
\hline \multirow{4}{*}{\begin{tabular}{l} 
District \\
\cline { 2 - 3 }
\end{tabular}} & Winter & \\
\cline { 2 - 3 } & Monsoon & \\
\hline
\end{tabular}

\begin{tabular}{|l|l|l|}
\hline \multirow{2}{*}{} & Summer & 3537.64 \\
\cline { 2 - 3 } & Total & 10331.39 \\
\hline $\begin{array}{l}\text { STATE } \\
\text { TRIPURA }\end{array}$ & GRAND TOTAL & $1,00,640.39$ \\
\hline
\end{tabular}

\section{CONSTRAINTS FOR ANIMAL HUSBANDRY IN}

\section{TRIPURA:}

\section{TABLE-7 VARIOUS CONSTRAINTS FOR ANIMAL HUSBANDRY IN} TRIPURA.

\begin{tabular}{|l|l|l|l|l|l|l|}
\hline $\begin{array}{l}\text { Con } \\
\text { strai } \\
\text { nts }\end{array}$ & $\begin{array}{l}\text { Non } \\
\text { availabi } \\
\text { lity of } \\
\text { regular } \\
\text { market } \\
\text { of Milk. }\end{array}$ & $\begin{array}{l}\text { Poor } \\
\text { infra } \\
\text { structur } \\
\text { e facilitie } \\
\text { s }\end{array}$ & $\begin{array}{l}\text { Less } \\
\text { Traini } \\
\text { ng } \\
\text { Progra } \\
\text { m-me }\end{array}$ & $\begin{array}{l}\text { Fodd } \\
\text { er } \\
\text { Short } \\
\text { age }\end{array}$ & $\begin{array}{l}\text { Land } \\
\text { labour } \\
\text { decrea } \\
\text { se }\end{array}$ & $\begin{array}{l}\text { Hig } \\
\text { h } \\
\text { Cost }\end{array}$ \\
\hline $\begin{array}{l}\text { Agar } \\
\text { tala }\end{array}$ & 100 & 100 & 60 & 100 & 70 & 80 \\
\hline
\end{tabular}

(Figures indicate percentage expert samples consulted)

Table -7 and bar diagram shows that there are the various constraints for Animal Husbandry in Tripura. $100 \%$ expert of Animal Husbandry Department said that their not getting proper market in Milk. 100\% expert of Animal Husbandry Department said that they don't have proper infrastructure facilities for Cross-Bred farming.60\% expert of Animal Husbandry Department said that their not getting sufficient training which they required. $100 \%$ expert of Animal Husbandry Department said that they are not getting sufficient feed and fodders for the cattles.One of the major constraints for cattle farmings is scarcity of land and labour.Finally $80 \%$ expert of Animal Husbandry Department facing the problems of high cost .

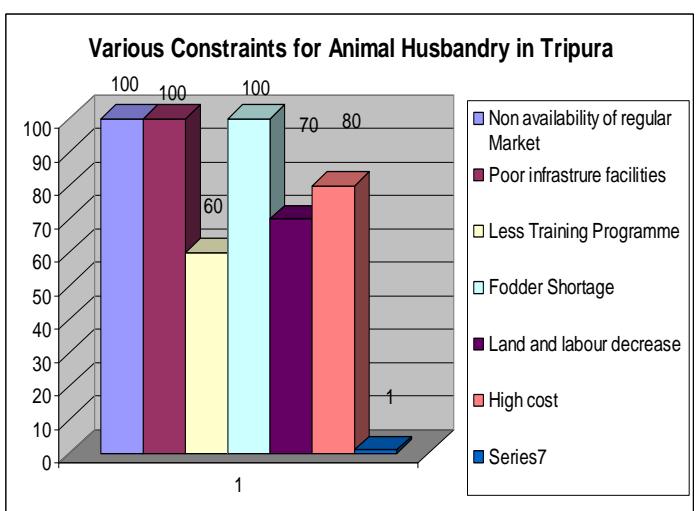


[6] http://www.articlesbase.com/self-publishingarticles/scenario-of-indian-agriculture-798281.html

Fig-1: VARIOUS CONSTRAINTS FOR ANIMAL HUSBANDRY IN TRIPURA.

\section{CONCLUSIONS}

The problems of the Agricultural Sector and Animal Husbandry in Tripura are serious and remedial measure should be taken to overcome these problems. Though SRI have given a remarkable achievement and changes in the agriculture crops mainly paddy but enough importance should also be given to the other crops like Maize, Bottle Gourd, Radish, Cauliflower, Sesamum, Rapeseed, Blackgram, Arhar, Pineapple, Banana, Ginger, Chili Bamboo, etc. Animal Husbandry Department also took various initiatives to for to increase the Cross Bred cattle cultivation to increase the Milk production. For this Agriculture and Animal Husbandry education, research and examination will play a very vital role. Agriculture and Animal Husbandry research should be spread to the very remote areas of Tripura so that small farmers can understand the advantage of Agricultural Sector and Animal Husbandry sector related research, education and extensions activities.

\section{ACKNOWLEDGEMENTS}

At the outset, I send my humble prayers to The Lord Almighty for giving me strength, courage and determination in pursuance of this task and also in the entire walk of my life and Iexpress my sincere thanks to my father, mother and brother.

I extend my sincere thanks to my research guide Prof \& HOD Dr.A.K.Ray whose total support, constant encouragement and excellent guidance in every stage of my research has enabled me to complete this manuscript successfully.

I thank Dr. Ashok Majumder vetty Asstt Surgeon,Govt of Tripura for his encouragement and support.

I gratefully record my deep sense of gratitude Agricultural Department Government Of Tripura for their support in the successful completion of this endeavor.

\section{REFERENCES}

[1] http://www.agritripura.in/Agriculture/Pages/50\%20YE ARS\%20IN\%20AGRICULTURE\%20IN\%20TRIPUR A\%20.pdf

[2] http://www.agritripura.in/Agriculture/Pages/agri.htm

[3]

http://mizoramexpress.com/index.php/2010/09/agricult ure-in-tripura-challenges-ahead/

[4] [4]http://www.iffco.nic.in/applications/Brihaspat.nsf/0/ 724cb9c9cf212c8165256aab001e1178/\$FILE/gcfai200 $0 . p d f$

[5] http://dacnet.nic.in/extension/document/chapter/3.htm
[7] agricoop.nic.in/Rabi-2010/Tripura.ppt

[8] http://www.ifpri.org/publication/agricultural-researchand-productivity-growth-india

[9] http://en.wikipedia.org/wiki/Agriculture_in_India

[10] http://icardablog.wordpress.com/2010/12/12/presidentof-india-keen-to-support-agricultural-research-in-dryareas/

[11] http://www.indiaagronet.com/indiaagronet/Indian\%20A griculture/mainagri.htm

[12] http://pashudhanharyana.gov.in/html/welschemes_HiTech\%20commercial\%20Dairy.htm

[13] 'Tripura State Archive, State Agriculture research Center, Arundhutinagar, Agartala City'.

[14] Tripura State Archive, State Animal Husbandry Department, Gurkhabasti,Agartala City.

\section{BIOGRAPHIES:}

Miltan Kumar Acharjee I did my MBA (Marketing and

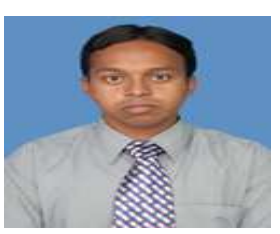
Finance Specialistion)in 2009.After that I joined as aLecturer in Management at Bhavan's Tripura College of Science \&Technology affiliated to Tripura University(A central University)Since 2009 to till date. I am doing Ph.D at National Institute of Technology(Govt Of India) Agartala at Humanities and Social Science Departmentat 2010 to till date.I have two ISBN publication and lot of seminar works ,workshop participationetc.

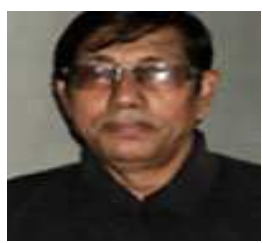

Ajit Kumar Ray, Proffessor \& HOD ,Humanities \&social Science Department at National Institute of Technology(Govt Of India),Agartala. Area of interest : Economics/ Rural Development 